The relationship between human societies and the environment is multidimensional and complex. Human societies are both shaped and constrained by the environment in which they exist, and in turn act to shape and alter that environment to suit their own needs.

\title{
Environmental Dimensions of Zionism in the Negev and the West Bank
}

Alice Gray is a British environmental scientist (MPhil, BSc) currently living and working in the West Bank. She is a founding member and project coordinator of LifeSource, an initiative to stimulate a grassroots movement for water access and sustainability in the Palestinian Territories and Israel. She also works with the Palestinian NGO Applied Research Institute, Jerusalem, and with the Israeli NGO Bustan. 
TEXT: Alice Gray

OVER TIME, the actions of humans within the environmental matrix in which they exist create a series of "cultural landscapes", dynamic products of the interaction of people and the environment ${ }^{\mathrm{T}}$ whereby human societies embed themselves within their environmental context. Under the influence of a given culture (which itself is changing), the landscape is transformed, reflecting the activities and values of the occupant society. ${ }^{2}$

In addition, the way in which human societies interact with each other is affected by and affects environmental variables. For example, either shortage or abundance of natural resources can create conflict between groups, or alternatively environmental crises can create demand for cooperation. In these cases, one can imagine a causal flow from the environment to the people, whereby environmental conditions affect the way in which groups of humans behave towards one another. Conversely, control over environmental resources and certain forms of environmental transformation can be used as a tool to manipulate the balance of power between groups, whereby shortage and abundance are artificially created and maintained, or environmental transformation is brought about, not necessarily as an end in itself, but to assert the control of one group over another, or as a consequence of ideologically motivated behaviour. In this case the causal flow is from human society to the environment, which is transformed due to complex social, cultural and political relations between groups of humans.

It is simplistic to suppose that humanenvironmental interactions can be easily divided into one category or the other (environment-driven or human-driven), or that anything as complex as human ideologies and inter-societal relations, or indeed shifts in ecosystem dynamics can be considered to be monocausal. Nevertheless, it is useful to be able to conceive of a circular relationship between people and the environment, and the potential for a kind of environmental homeostasis, whereby human values and behaviour patterns may alter in response to changing environmental conditions, which in turn were brought about as a result of human values and behaviour patterns.

In this paper I will analyse the way in which the Zionist project in historic Palestine has acted to transform the environment in the Negev/Naqab (Hebrew/Arabic) desert and the West Bank, the motivations for and environmental consequences of this behaviour, and the necessity that has 
been created for a paradigm shift in environmental policy and management throughout the region.

\section{The colonization of the Negev}

The Negev has been included in Israeli territory since the formation of the State in I948, when it was captured in the 1948 Israeli-Arab War, and comprises nearly two thirds of the land mass within Israel's international borders. "Negev development" has been and continues to be a central component of Israeli national planning. There are several components to Israeli strategy in the Negev. As an area that is bordered by Egypt to the west, Jordan to the east and the West Bank to the north, in addition to forming a land corridor to the commercially important port of Eilat on the Red Sea, "national security" has been a key factor in shaping Israeli policy in the Negev. As soon as it was captured, the Negev was declared a "closed military area", and to this day, approximately 85 percent of the land is used as a military training ground, and contains a strong Israeli military presence.

In addition, the establishment of Jewish settlements has served as a means of strengthening Israel's position in the Negev by establishing political "facts on the ground". Even before the State of Israel came into being, Zionists had established I9 Jewish settlements in the Negev (3 in I943, II in I946 and 5 in I947). ${ }^{3}$ Zionist ideology has a visionary side that has also impacted the way in which Israel has gone about settling the Negev. The concept of "redeeming" or "improving" the landscape, the famous Zionist ideal of "making the desert bloom", has been a determinant factor in shaping behaviour: "[A]nd the scorched land will become a pool, and the thirsty ground springs of water." (The Torah, Isaiah 35:7). In addition to this, "selfsufficiency" was a key concern for Zionists, particularly in the aftermath of the Holocaust. Israel and the Jewish people were to be reliant upon the good will of no other country, and would have the capacity to produce sufficient food resources to sustain the population (a form of "environmental security"). For these reasons, settlements in the Negev were always intended to be agricultural in nature.

The act of colonization, a form of cultural intrusion, generates an entirely new set of landscape features which are superimposed on the existing cultural landscape. In

\section{The way human societies interact with each other is affected by and affects the environmental variables.}

the case of settler societies, their activities are often based upon the assumptions of terra nullius or an "empty land" whereby the civilising project subsequently transforms "wilderness" into "garden". ${ }^{4}$ Contrary to popular myth, the Negev was far from an empty wasteland when the State of Israel was established. Prior to I948, the Negev's population consisted of around 70,000 Bedouin, living mainly in the northern and north-western parts of the Negev and cultivating and grazing approximately 2 million dunums (200,000 ha.) of land. ${ }^{5}$ Far from an unmanaged wilderness, the Negev at that time reflected the activities and culture of the Bedouin people. Soil quality and species composition were 
affected by the grazing activities of Bedouin herds, and subsistence agriculture was widely practiced by Bedouin communities. ${ }^{6}$ In addition, the landscape was mapped into a wider network of tribal estates and resource components, with land and water rights being governed by a complex cultural code.

During and after Israel's "War of Independence”, approximately 55,000 Bedouin were driven out of the country or fled, reducing the population from 70,000 to around II,০o0.? As was the case with all Palestinian refugees, the Bedouin were denied the right to return, freeing up their former lands in the fertile northwest for settlement by Jewish communities. Within a few years, some 50 Jewish settlements had been established on lands vacated by the Bedouin. ${ }^{8}$

The character of the Jewish settlements reflected the values and ideology of the new incumbents. For the colonists, agriculture constituted a recognizable cultural symbol of land ownership and "civilization". 9 The nomadic behaviour and subsistence agriculture practiced by the Bedouin were perceived as illegitimate forms of land tenure compared to the "productive" styles and closer settlement of the Zionist enterprise. The transformation of the landscape towards what was (and presumably still is) considered a higher phase of "development" subsequently justified dispossession of the Bedouin.

The vacated land was an important resource to absorb and settle many of the hundreds of thousands of Jewish immigrants who flooded into the newly formed State during its first decade in existence. The colonial "gaze" of the settlement project however, led to a systematic failure to recognize the value of the desert environment or the cultural landscapes of Bedouin. Many of the architects of the Zionist colonization of the Negev were of European origin, and their encounter with an alien environment and nostalgia for European familiarity created an additional drive which sought to modify the landscape to more closely resemble the lands from which they had fled. Greening the desert was the order of the day, and this required water.

Zionist plans to convey water to the Negev began in I939 and continued through the I940s, with a number of studies being published by Jewish and American experts on the possibilities for developing water resources in the Land of Palestine. ${ }^{\text {Io }}$ These culminated in the construction of the Yarkon-Negev pipeline in I955, and the Israeli National Water Carrier in I964. ${ }^{\text {II }}$ The National Water carrier stretches all the way from Lake Tiberias (also known as Lake Kinneret or the Sea of Galilee) in the north to the Negev in the south, joining with the Yarkon-Negev line. It transfers water not only from Lake Tiberias (400$500 \mathrm{MCM})$ but also from the Coastal Aquifer (250 MCM) and the Mountain Aquifer (350 MCM), which underlies the West Bank. ${ }^{\mathrm{I}}$

There is no doubt that since Israel was established in I948, the construction of the National Water Carrier has significantly facilitated the development of a successful agricultural sector. The total area under cultivation has increased from I65,000 ha. to some 435,000 ha. and the number of agricultural communities has grown from 400 to 900 (including I36 Arab villages). During the same period, agricultural production has expanded I6-fold, more than three 
times the rate of the population growth. ${ }^{13}$ However, the environmental consequences of this development have been significant. The Yarkon River underwent severe degradation following the building of the Yarkon-Negev pipeline in $1955,{ }^{\mathrm{I} 4}$ and river ecosystems and associated wetlands suffered. In the case of the Lower Jordan River and the Dead Sea, consequences were even more severe, as the Israeli National Water Carrier in combination with the Jordanian East Ghor Canal diverted the majority of water that used to flow in the Lower Jordan to agricultural projects in Jordan and Israel. The Lower Jordan once discharged 1320 MCM into the Dead Sea, whereas that flow is now reduced to less than 250 MCM of poor quality water, ${ }^{15}$ resulting in the destruction of the river's ecosystem and associated wetlands, and a massive drop in level of the Dead Sea.

In addition to the direct environmental effects of withdrawing such large quantities of water from the Jordan and Yarkon Rivers, the conversion of large swathes of rangeland to irrigated farmland can increase the risk of soil erosion and salinization; through removing stabilizing scrub vegetation from hillsides and loosening top-soil by repeated ploughing, and by heavy deposition of salts and minerals close to the soil surface by irrigation water and heavy use of fertilizers. ${ }^{16}$ In conjunction with global climate change, which is likely to produce a decrease in rainfall over the Negev, there are serious risks of irreversible damage to natural water resources and desertification which Israel must deal with in the twenty-first century. There is a need for a shift from a paradigm of being masters of an endlessly pliable environment which can be modified to supply all human needs, to a paradigm of maintaining a delicate environmental balance and controlling human demands and impacts to avoid causing irreversible damage. This consciousness is beginning to emerge in Israel, with much focus in research institutes and government agencies on controlling and ameliorating environmental impacts and reducing fresh water use in agriculture. ${ }^{17}$

However, the environmental impact of the colonization of the Negev is not limited to the impact of the Jewish colonists themselves. The remaining II,000 Bedouin were concentrated in a small area of land in the north-east Negev, known as the Siyag. ${ }^{\text {. }}$ The fate of this remaining population and their environmental impact are also vital determining factors in the story of the Negev.

\section{The Siyag and the modern Bedouin}

The Zionist project for the Negev did not stop at merely displacing the Bedouin from the most fertile lands, but also extended to undermining and attacking Bedouin culture. In I937, David Ben Gurion wrote to his son: "Naqab/Negev land is reserved for Jewish citizens, whenever and wherever they want... We must expel the Arabs and take their places." Short of expulsion, destruction of the Bedouin culture, disconnection of the Bedouin from their land and concentration of the Bedouin into the smallest area possible was chosen as a viable alternative that would still ensure the ability of Jewish immigrants to settle the Negev. ${ }^{19}$ Essentially the Zionists established an "ethnocracy" over the region, whereby resources and power are allocated not on

Lonely tree at the Vadi Peress in the Negev. 


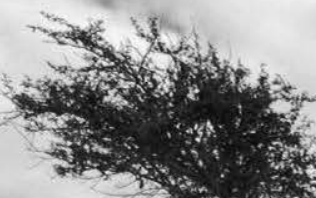

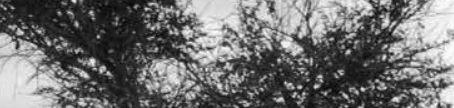

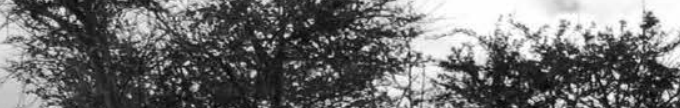

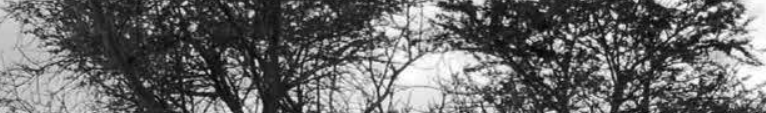

1.t.

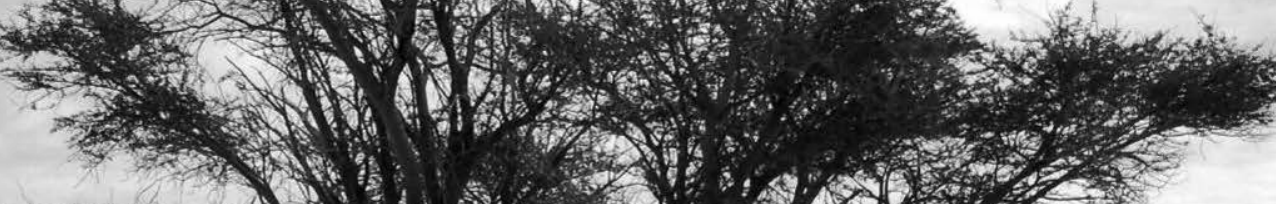

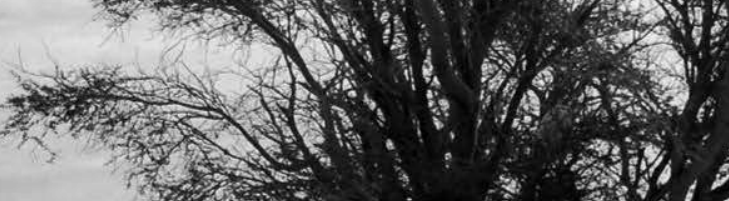

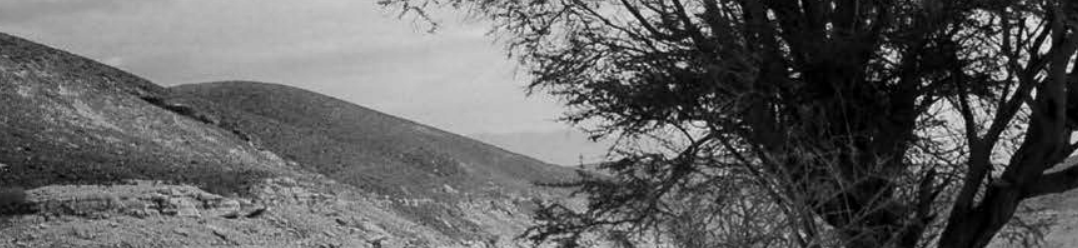

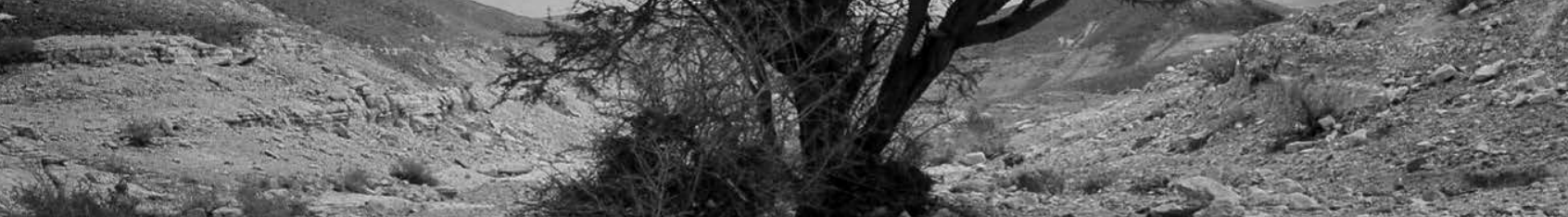

R.

5

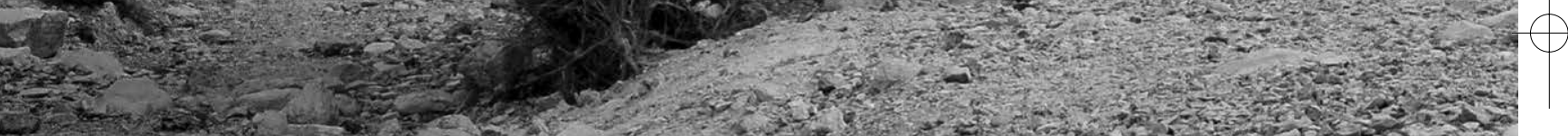

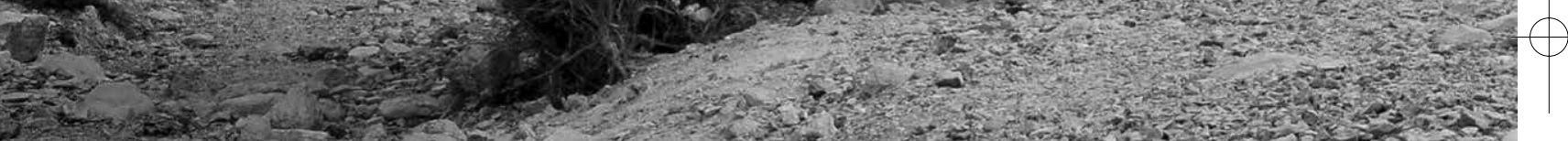

ben

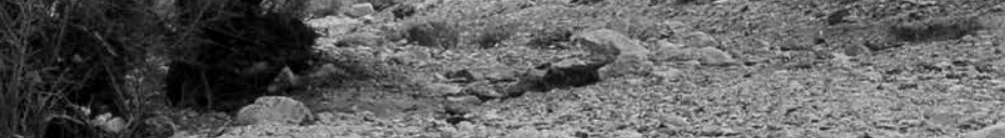

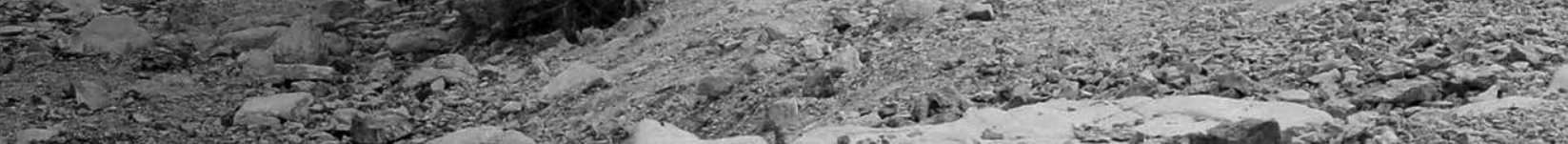

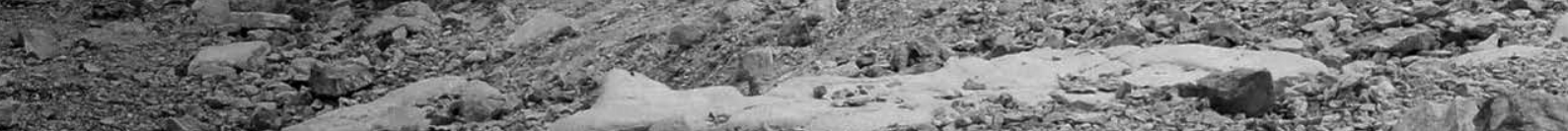

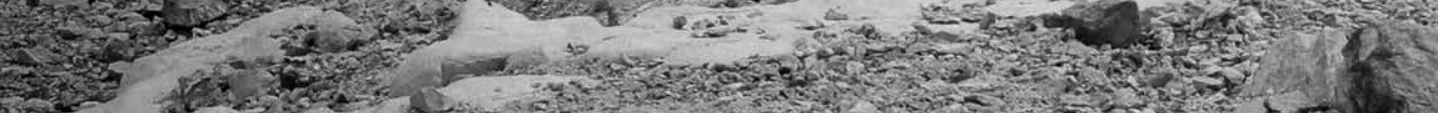

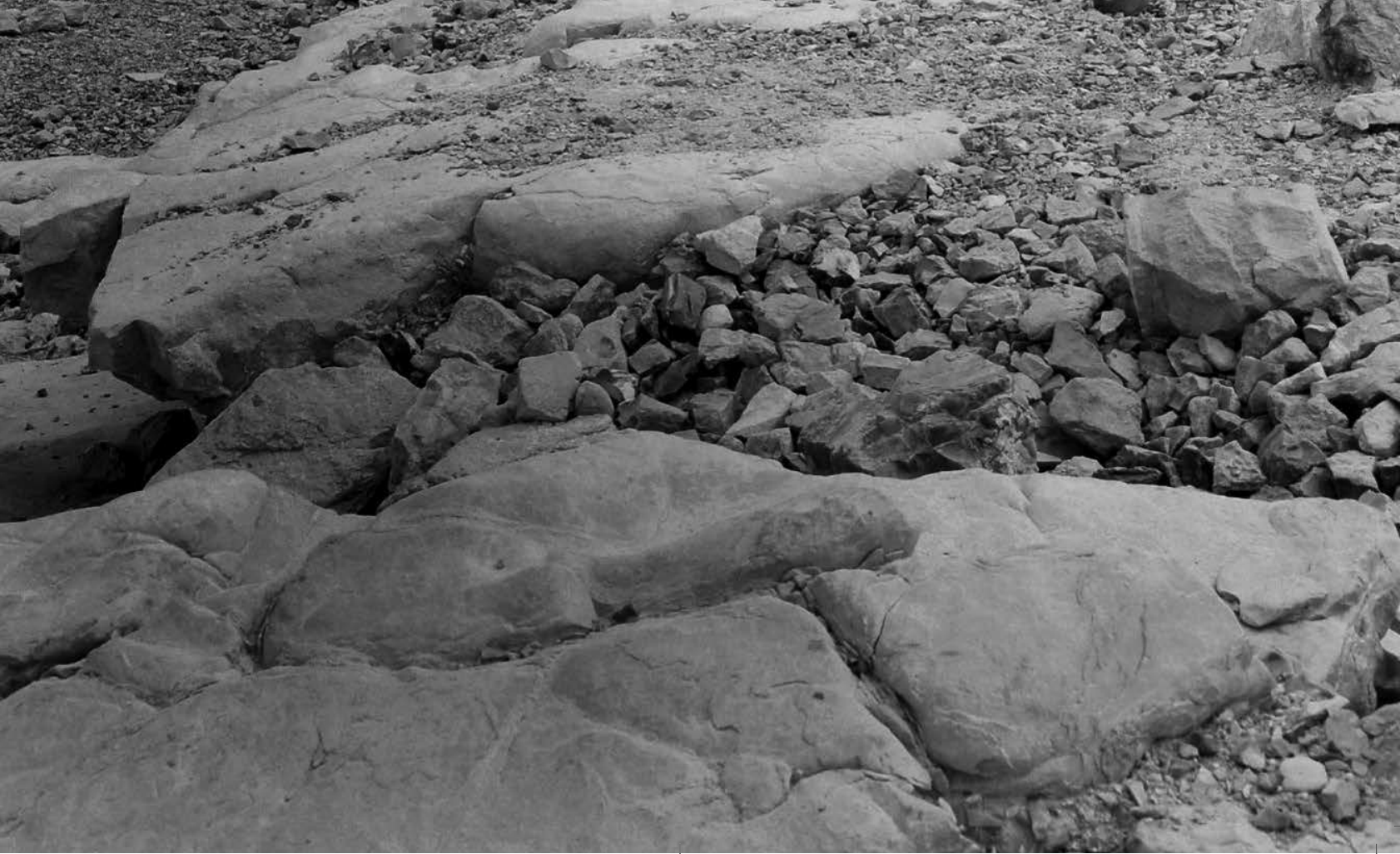


the basis of citizenship, but on the basis of ethnicity (in this case "Jewishness"). Thus, both the state apparatus and policy-making power are appropriated by one dominant ethnic group..$^{20}$

Like other Palestinian Arabs who remained within the borders of the new Israeli State and became Israeli citizens between I948 and I980, the Bedouin were immediately placed under military rule,

which lasted until I966. ${ }^{21}$ Military restrictions on movement were partly motivated by security considerations, and partly by the desire to disconnect the Bedouin from their former lands and free up the area for Jewish settlement. In I950, the Black Goat Law was passed, prohibiting the grazing of goats outside one's own holdings. At the same time, the State refused to recognize Bedouin land rights, and passed the I953 Land Acquisition Law, formally asserting State ownership over 93 percent of the Negev. ${ }^{22}$ Bedouin were not allowed to rent farmland due to a Zionist prohibition against leasing land to non-Jews. Thus Bedouin were legally debarred from all traditional means of self-support, and following the end of a decade long ban on hiring non-Jewish labour, began to migrate north in search of work. ${ }^{23}$

In I963, Moshe Dayan, then Minister of Agriculture, was quoted in the Israeli daily Haaretz saying:
"We should transform the Bedouins into an urban proletariat ... 88 percent of the Israeli population are not farmers, let the Bedouins be like them ... Without coercion but with government direction ... this phenomenon of the Bedouin will disappear. ${ }^{24}$

In I969, the first Bedouin township of Tel Sheva was founded, followed by Rahat in I97I. Five more townships followed, although the pace of construction was slow, with the last of them, Hora, being finished in I985. Bedouin were moved to these townships through a mixture of compensation and coercion. By moving to a township, a Bedouin would relinquish all land claims he might have in return for receiving some financial compensation and municipal services in the government township. Bedouin who did not move to townships were designated as "squatters" and "trespassers" on the appropriated State land, forbidden from building permanent structures or farming any land, and excluded from receiving any basic services such as electricity or piped water. The level of compensation offered to the Bedouin was extremely low, ${ }^{25}$ in addition to the fact that all government planned townships were urban in character, precluding practice of any form of agriculture.

It should be noted that Jewish development in the Siyag continued apace in conjunction with the concentration of the Bedouin. New towns, farming communities, factories, chemical plants, power stations and a military airport were constructed. The Jewish population of the Siyag reached close to 350,000. Today, the Bedouin population of the Negev has grown to about I70,000, approximately 27 percent of the population of the Siyag, how- 
ever occupying only five percent of the land. ${ }^{26}$ Slightly over half of the Bedouins live in government planned townships, with the other half (close to 80,000 people) residing in 45 so-called "unrecognized villages", communities whose presence on what is now designated as Israeli State land is considered to be illegal by the government. In addition to not receiving basic services such as piped water and electricity, these villages lack services such as sewage infrastructure and garbage collection, clearly not provided for political reasons. ${ }^{27}$

The result of this gridlock is environmental degradation (not to mention human suffering). The Bedouin of the "unrecognized villages" do not have access to sufficient land or funds to build sanitary landfills. ${ }^{28}$ Open dumping of solid wastes in and around Bedouin settlements is endemic and can lead to the contamination of ground water through leachate, soil contamination by direct waste contact or leachate, and air pollution from burning of wastes in the dumps. ${ }^{29}$ Open discharge of untreated sewage, or storage in unlined cesspits also leads to soil and groundwater contamination. Both air and groundwater contamination affects not only the Bedouin communities generating them, but also all users of the same groundwater supplies and breathers of the same air in the vicinity. Not only the "unrecognized villages", but also the government planned townships suffer from inadequate municipal services and associated environmental degradation, largely as a result of inadequate budgets allocated by the government..$^{30}$ In addition, the lack of access to grazing lands creates overgrazing in the areas that are available to Bedouin herds, and associated loss of biodiversity and soil erosion. It should be noted that managed grazing has the potential to increase plant biodiversity, however, this option is not available to the Bedouin, due to State imposed restrictions. The amount of environmental damage that can be done by I70,000 people denied the right and the means to exercise effective environmental management is considerable. However, the situation in the Negev pales into insignificance compared to the degradation that is occurring in the nearby West Bank.

\section{The colonization of the West Bank}

The West Bank territory was captured by Israel during the ${ }_{9} 6_{7}$ War. One of the very first actions of the military government was to declare all water resources in the area to be Israeli State property (Military Order Number 2, June $7^{\text {th }}$ I967). This was followed by a series of subsequent orders that fixed pumping quotas, banned Palestinians from digging new wells or rehabilitating existing wells without a permit, and declared all previous settlements of water disputes to be invalid..$^{3 \mathrm{I}}$ All Palestinian pumping stations on the Jordan River were destroyed during and after the fighting,

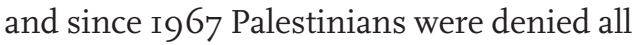
access to the Jordan River. This assertion of Israeli hydro-hegemony in the West Bank ${ }^{32}$ was central to protecting the continuation and expansion of irrigated agriculture projects in the Negev, since much of the water for these projects was drawn from the Jordan River system and the Mountain Aquifer underlying the West Bank via the National Water Carrier. Palestinian water development, particularly on the Yarkon Taninim Aquifer (the Western Basin of the Mountain Aquifer system) was perceived as a threat to Israeli interests, and so was 


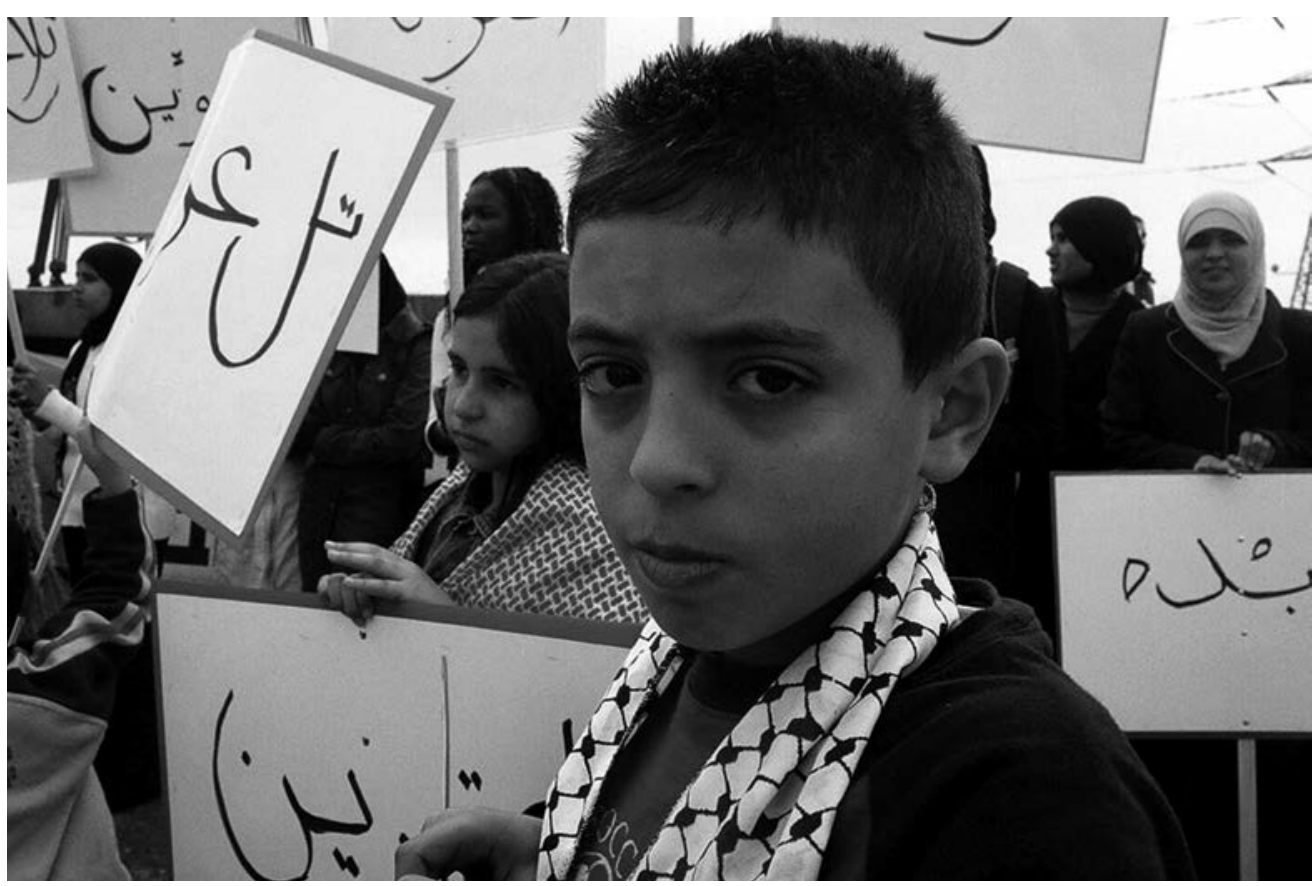

Demonstration organized by Arab organizations to express solidarity with the Arabs living in the unrecognized Negev villages.

prevented. Thus, Palestinians were prevented from developing any significant irrigated agricultural sector, and many communities suffered severe water shortages.

At the same time, a colonization drive began with the construction of Israeli settlements inside the West Bank. With the exception of East Jerusalem, which was annexed immediately for ideological reasons, areas along the Jordan River and Dead Sea and around Jerusalem were initially annexed for "security reasons" in line with the Allon Plan. ${ }^{33}$ However, in I977 the right-wing Likud Party came to power in Israel, and the settlement drive in the West Bank gathered momentum in an attempt to assert Israeli sovereignty over the whole of the occupied Palestinian Territories, in an ideologically motivated drive to create "Greater Israel", stretching from the Jordan River to the Mediterranean Sea. This colonization drive had much in common with the earlier efforts to settle the Negev. Large swathes of land were confiscated from Palestinians, and converted to Israeli agroindustrial projects. Particularly in the Jordan valley, large-scale irrigated agriculture was widely implemented. More than 32 deep wells were dug inside the West Bank territory to supply water to the settlements, ${ }^{34}$ withdrawing around $66 \mathrm{MCM}$ from the Eastern Basin of the Mountain Aquifer. These wells caused the drying up of many shallower Palestinian wells, due to the dropping water table. Palestinian wells were not allowed to be rehabilitated or deepened, and due to this and to loss of access to wells due to military closures, the number of functioning Palestinian wells dropped from $4 \mathrm{I} 3$ in 1967 to 300 in $1983 .{ }^{35}$

Until I995 the occupied Palestinian territories were under the authority of the Israeli Civil Administration (CA). They were responsible for administering all eco- 
nomic matters including granting licenses and permits, regulating trade, collecting taxes, organizing public infrastructure and services, and supervising the operations of local governments. Underinvestment in and poor management of Palestinian public infrastructure development was endemic to the system. Not all taxes paid by Palestinians accrued to the development budgets of the CA and the Municipalities; large amounts ended up in the Israeli treasury. ${ }^{36}$ Furthermore, development was poorly coordinated and planned. The paucity of public services in Palestinian areas was in marked contrast to the well-designed and well-maintained infrastructure catering to the needs of Israeli settlements. ${ }^{37}$ In I993, a World Bank report noted that the provision of infrastructure and public services to Palestinian communities was "highly inadequate" and warned that "the poor management of wastewater is contributing to the contamination of groundwater" ${ }^{38} \mathrm{As}$ is the Negev, second rate services or no services at all were being given to non-Jewish localities, contributing to the establishment of Jewish ethnocracy. And, as in the Negev, the environmental consequences have been severe, leading to pollution of soil, air and groundwater by poor waste management practices. The Mountain Aquifer, 83 percent of which underlies the West Bank, supplies 30 percent of Israel's annual fresh water consumption, and close to roo percent of West Bank Palestinian water consumption. Contamination of this vital resource has dire implications for both Israeli and Palestinian populations.

Following the I993 Oslo Agreement and the subsequent establishment of the Palestinian Authority, it was hoped that progress could be made in developing adequate water supplies, water and wastewater infrastructure and municipal waste services to ensure a decent standard of living for the population and environmental protection and sustainability. However, despite high levels of investment by the international donor community, progress has been extremely slow. ${ }^{39}$ To a large degree, this is due to the continued Israeli military occupation of the West Bank, where close to 80 percent of land is still under Israeli military control (Areas B and C), and 60 percent is under Israeli civil control (Area C).

Under the terms of the Oslo Interim Agreement, Palestinian water and wastewater development must be approved by a Joint Water Council before it can go forward, and any form of development in Area $\mathrm{C}$ requires approval by the military authorities. Thus, for Palestinian communities practicing any form of effective environmental management is extremely problematic because they do not have full sovereignty over land and resources..$^{\circ}$ Since Oslo, there has been much criticism of Israeli obstruction of Palestinian development by Palestinian and international development experts, ${ }^{4 \mathrm{I}}$ who cite Israeli obstruction as a key obstacle to effective development. This obstruction is sometimes related to a form of "horse-trading", whereby Israeli negotiators will make approval for Palestinian infrastructure projects contingent upon Palestinian approval for infrastructure projects for illegal settlements, thus leading to gridlock. ${ }^{42}$ The result is that $\mathrm{I} 3$ percent of the Palestinian population of the West Bank (over 200,000 people) remain unconnected to any form of water network, and there is only one functioning sewage treatment plant (at Al Bireh, near Ramallah) to serve 
a population of over 2 million, with the majority of sewage being discharged untreated into the environment. ${ }^{43}$

\section{Conclusion}

The nature of the Zionist colonization of the Negev and the West Bank has essentially been shaped by two major paradigms. The first is the "transformation", "improvement" or "redemption" of the land, turning "wilderness" to "garden", necessitating the implementation of huge environmental engineering projects to provide the water necessary for this venture. The second is the concept of "ethnocracy", whereby resources have been primarily reserved for Jewish use, and the indigenous Palestinian population have essentially been disenfranchised from access to resources and the agency to manage their own affairs or the environment around them.

The outcome of this policy in environmental terms is disastrous, as growing populations with inadequate infrastructure to manage the waste they produce cause wide-scale pollution of the environment, damaging resources that sustain all the people of the area. There is a great need for recognition of this phenomenon, and for a reversal of the current policy, not only for humanitarian reasons, but also in order to prevent irreversible environmental degradation that will ultimately hurt everybody, Palestinians and Jews alike.

\section{$\cdot f \cdot$}

I Norton, W: Explorations in the Understanding of Landscape: A Cultural Geography. Greenwood Press, New York, 1989

2 Sauer, Carl: "The Morphology of Landscape" i University of California Publications in Geography, vol. 2, I925.

3 Sitton, Dov: Development of Limited Water Resources: Historical and Technological Aspects. Israeli Ministry of
Foreign Affairs, 1997

4 Head, L.: “'Unearthing Prehistoric Cultural Landscapes: A view from Australia" i Transactions of the Institute of British Geographers, vol. I8, 1993 and Sluyter, A.: "Colonialism and Landscape in the Americas: Material/ Conceptual Transformations and Continuing Consequences" i Annals of the Association of American Geographers, vol. 9I, no. 2, $200 \mathrm{I}$

5 Swirski, Shlomo and Hasson, Yael: Invisible Citizens: Israeli Governmental Policy toward the Negev Bedouin. Adva Center, Tel Aviv, 2006 and Porat, Chanina: "Israel's Policy on the Bedouin Issue and Left-Wing Alternatives, 1953-1960" i Iyyunim BiTekumat Israel. (in Hebrew) vol. I5, 2000.

6 Blaustein Institute for Desert Research, Ben Gurion University of the Negev: First National Reporton the Implementation of the United Nations Convention to Combat Desertification. Israeli Ministry of Foreign Affairs, 2000

7 Ben-David, Yosef: Conflict in the Negev: Bedouin, Jews, Land. (in Hebrew). Kav HaTever: Studies on Arabic Society in Israel, I996.

8 Yiftachel, Oren: "Bedouin Arabs and the Israeli Settler State: Land, Policies and Indigenous Resistance" i The Future of Indigenous People: Strategies for Survival and Development. UC Press, Los Angeles, 2003.

9 Powell, Owen: Valuing Indigenous Cultural Landscapes, James Cook University, Cairns (in press), 2007.

Io Sitton, Dov: Development of Limited Water Resources: Historical and Technological Aspects. Israeli Ministry of Foreign Affairs, I997

II Ibid.

I2 Ibid. and Murakami: Managing Water for Peace in the Middle East: Alternative Strategies. United Nations Press, Tokyo-New York-Paris, I995.

I3 Fedler, Jon: Israeli Agriculture: Coping with Growth. Israeli Ministry of Foreign Affairs, 2007.

I4 Israeli Ministry of Environmental Affairs: Yarkon River, 2005

I5 Executive Action Team: Overview of Middle East Water Resources: Water Resources of Jordanian, Palestinian and Israeli Interest. Jordanian Ministry of Water and Irrigation, Palestinian Water Authority and Israeli Hydrological Service, compiled by the US Geological Survey, I998.

I6 Blaustein Institute for Desert Research, Ben Gurion University of the Negev: First National Reporton the Implementation of the United Nations Convention to Combat Desertification. Israeli Ministry of Foreign Affairs, 2000

I7 Blaustein Institute for Desert Research, Ben Gurion University of the Negev: Report on the National Planning Workshop I999-200I of the Initiative for Collaboration to Control Natural Resources Degradation (Desertification) of Arid Lands in the Middle East. Facilitation Unit, Cairo, 1999 and Israeli Ministry of Environment: Towards Sustainable Development in Israel. Background documents for a national workshop on sustainable development. UNEP/MAP Coastal Areas Management Program 
for Israel. Ministry of Environment, Jerusalem, I996.

I8 Swirski, Shlomo and Hasson, Yael: Invisible Citizens: Israeli Governmental Policy toward the Negev Bedouin. Adva Center, Tel Aviv, 2006.

I9 Ibid.

20 Yiftachel, Oren and Ghanem As'ad: "Understanding Ethnocratic Regimes: The Politics of Seizing Contested Territories" i Political Geography, vol. 23, 2004.

2I Swirski, Shlomo and Hasson, Yael: Invisible Citizens: Israeli Governmental Policy toward the Negev Bedouin. Adva Center, Tel Aviv, 2006.

22 Manski, Rebecca: "The Scene of Many Crimes: Suffocating Negev Arab Self-Subsistence" i News From Within, Jerusalem, March 2007.

23 Ibid.

24 Dayan, Moshe, i Haaretz, July 3ist, I963.

25 Ibid.

26 Negev Coexistence Forum for Civil Equality: The ArabBedouins of the Neqab-Negev Desert. UN Committee on the Elimination of Racial Discrimination (CERD), 2006.

27 Almi, Orly: Water, the State and the Unrecognized Villages in the Negev. Physicians for Human Rights, Israel, 2006.

28 Meallem, Ilana: The Management of Solid Waste in Rec ognized and Unrecognized Bedouin Villages of the Negev: Social Context, Impacts and Recommendations. (Final thesis) Blaustein Institute for Desert Research, Ben Gurion University of the Negev, 2006.

29 Ibid.

30 Ibid. and Swirski, Shlomo and Hasson, Yael: Invisible Citizens: Israeli Governmental Policy toward the Negev Bedouin. Adva Center, Tel Aviv, 2006.

3I United Nation Environment Program: Desk Study on the Environment in the Occupied Palestinian Territories. United Nations, 2003, and Gray, Alice and Hilal, Jane: "The water crisis in the Palestinian Territories: Challenges and Opportunities for Development." i Integrated Water Resources Management and Security in the Middle East. Springer, 2007

32 Zeitoun, Mark and Warner Jeroen: "Hydro-hegemony - a Framework for Analysis of Trans-boundary Water Conflicts" i Water Policy, vol. 8, no. 5, 2006.

33 Reuveny, R: "Fundamentalist Colonialism: the Geopolitics of Israel-Palestinian Conflict” i Political Geography, vol. 22, 2003

34 Trottier, Julie: Hydropolitics in the West Bank and Gaza Strip. Palestinian Academic Society for the Study of International Affairs (PASSIA), Jerusalem, I999.

35 Nasser, Y: "Palestinian Water Needs and Rights in the Context of Past and Future Development" i Water in Palestine: Problems - Politics - Prospects. Palestinian Academic Society for the Study of International Affairs
(PASSIA), Jerusalem, 2003.

36 World Bank: Developing the Occupied Territories - An Investment in Peace. Washington, USA, I993.

37 Foundation for Middle East Peace: The Socioeconomic impact of Settlement on land, water and the Palestinian Economy. Foundation for Middle East Peace, Washington DC, 1998.

38 World Bank: Developing the Occupied Territories - An Investment in Peace. Washington, USA, I993.

39 Jansen, Pascal and Consulting Team: Water Sector Review. Austrian Development Cooperation, Ramallah, 2007.

40 Gray, Alice: "Environmental Justice for Palestine" i CounterCurrents, (www.countercurrents.org), 23 March 2007.

4I Jansen, Pascal and Consulting Team: Water Sector Review. Austrian Development Cooperation, Ramallah, 2007, Palestinian Water Authority: Well Status in the Drilling Sub-Committee. Directorate General of Resources and Planning, Palestinian Water Authority (PWA), Ramallah, 2003, and Gray, Alice: "Water Development in the Palestinian Territories Since Oslo: Obstacles to Progress and the Current Crisis" i The Journal for Palestine Studies, in press, 2007.

42 Selby, Jan: Water, Power and Politics in the Middle East the other Israeli-Palestinian conflict. I B Taurus and Co Ltd., London - New York., 2003.

43 Tagar, Zach; Keinan, Tamar and Qumsieh, Violet: Pollution of the Mountain Aquifer with Sewage: Finding Solutions. Friends of the Earth Middle East, 2006. 